Histoacryl tissue adhesive has potential as a splinting material for avulsed teeth. It is particularly useful when there are no adjacent teeth or, as in this case, when the adjacent teeth have been fractured at the level of the gum and are not available for splinting. Contact of the adhesive with periodontal membranes must be avoided. Reimplantation can be done by junior staff fairly easily, thus avoiding delay, especially in accident departments where there are no dental staff on site. A prospective study is needed to evaluate the long term effects of the adhesive as a dental splint in an emergency.

I thank Mr T P Welch for permission to report this case, the photography unit at the Clinical Research Centre for its help, and the patient's dentist for allowing me to follow up the patient's progress.

1 Mackie IC, Hobson P. Inappropriate dental care in casualty departments. BrMed F 1988;296:719-20.

2 Morton RJ, Gibson MF, Sloan JP. The use of histoacryl tissue adhesive for the primary closure of scalp wounds. Arch Emerg Med 1988;5:110-2.

3 Clarkson J, Welbury RR. Treatment of avulsed anterior permanent teeth in the accident and emergency department. British fournal of Accident and Emergency Medicine 1988;3:6-7.

4 Kehoe JC. Splinting and replantation after traumatic avulsion. $7 \mathrm{Am}$ Dent Assoc 1986;112:224-30

5 Mackie IC, Warren VN. Paedontics. Dental trauma. 3. Splinting, displacement injuries, and root fractures of immature permanent incisor teeth. Dental Update 1988;15:332-5.

(Accepted 16 May 1990)

\section{Two patients with eosinophilia myalgia syndrome associated with tryptophan}

\author{
Lucas Georges M M van Garsse, \\ Peter Paul H Boeykens
}

Stedelijk Ziekenhuis, 9330 Dendermonde, Belgium Lucas Georges $M M$ van Garsse, MD, chief physician Peter Paul H Boeykens, MD, adjunct

Correspondence to: $\mathrm{Dr}$ van Garsse.

BrMed f 1990;301:21
On 11 November 1989, after reports of cases of a so called eosinophilia myalgia syndrome, the Food and Drug Administration advised stopping the use of preparations containing tryptophan. ${ }^{1}$ A virtually unequivocal epidemiological relation had been found between the use of tablets containing tryptophan and this syndome,${ }^{1-4}$ which is characterised by an intense eosinophilia and myalgia. Arthralgia, swelling of the extremities, rash, fever, cough, interstitial lung disease, arryhthmias; ascending polyneuropathy, and sclerodermiform skin thickening have also been described. ${ }^{4}$

As no cases of the syndrome have yet been reported in Europe the question arises of whether the syndrome can possibly be explained by contaminants in the American preparations. ${ }^{5}$ However, we report on two patients with an eosinophilia myalgia syndrome for whom the tryptophan seemed not to have been supplied by an American pharmaceutical company.

\section{Case reports}

Case 1-A 28 year old woman with a history of hyperventilation started taking tryptophan $500 \mathrm{mg}$ thrice daily at the end of August. At the beginning of December she experienced muscle rigidity and pain in her arms and legs as well as pruritus in the shoulders, and tryptophan was stopped in mid-December. The muscular pains got worse and the patient was given phenylbutäzone $200 \mathrm{mg}$ daily from 23 December. She also complained of a flush on her arms and legs. On 27 December the clinical examination showed no abnormalities other than pain on palpation of the muscles and a minor spotty erythema on the legs. Results of blood tests are shown in the table. In January 1989 the results of a blood cell count and cell smear had been normal. The erythrocyte sedimentation rate was normal $(8 \mathrm{~mm} / \mathrm{h})$. Creatine kinase activity was normal. Tests for rheumatoid factors yielded negative results, and concentrations of complement and immunoglobulins, including IgE were normal. Results of the antinuclear antibody test in a titre of 160 showed a homogeneous pattern of fluorescence and results of lupus erythematosus and anti-DNA tests were negative. Lactate dehydrogenase activity was moderately increased with a raised third fraction. Results of other tests were normal. No parasites were found in the stool. A marrow aspiration showed a strikingly high number of eosinophils without other abnormalities.
Ultrasonography of the upper abdomen showed no abnormalities; an electromyogram was normal; and chest $x$ ray films were normal except for a slightly intensified interstitial pattern. Pulmonary function tests showed only a slight decrease in diffusion capacity. A skin and muscle biopsy showed discrete vasculitis in the subcutaneous tissue but no pathological changes in the muscle and fascia.

Case 2-A 60 year old woman with complaints of sleeplessness started taking tryptophan $1000 \mathrm{mg}$ four times daily at the beginning of August. From the middle of December she experienced generalised muscle pain and stiffness and pruritus, cough, and an intermittent mild fever. She described a feeling of fatigue and had swelling of the extremities. At the beginning of February tryptophan was stopped. Results of a clinical examination at that time were normal except for a discrete oedema of the extremities and a diffuse muscular tenderness. Results of laboratory tests showed an important eosinophilia (table). The

Characteristics of two patients with eosinophilia myalgia syndrome

\begin{tabular}{lcc}
\hline & Case 1 & Case 2 \\
\hline Dosage of tryptophan & $\begin{array}{c}500 \mathrm{mg} \\
\text { thrice daily }\end{array}$ & $\begin{array}{c}1000 \mathrm{mg} \\
\text { four times daily } \\
27 \mathrm{weeks}\end{array}$ \\
$\begin{array}{l}16 \text { weeks } \\
\text { Duration of intake }\end{array}$ & $22 \cdot 5 \times 10^{4} / 1$ \\
Leucocyte count at first visit & $32 \cdot 5 \times 10^{\natural} / 1$ & 52 \\
\% Of leucocytes: & 38 & 12 \\
$\quad$ Neutrophils & 13 & 1 \\
$\quad$ Lymphocytes & 2 & 35 \\
Monocytes & 46 & 3 \\
Eosinophils & & \\
$\quad$ Bands (juvenile forms) & & \\
$\quad$ Metamyelocytes & 1 & \\
Basophils & &
\end{tabular}

${ }^{\star}$ Normal range $4 \cdot 0-11 \cdot 0 \times 10^{\circ}$ cells $/ 1$.

other results were normal except for increased activity of lactate dehydrogenase. Chest $x$ ray films were normal, as were the results of ultrasonography of the abdomen and electromyography.

\section{Comment}

Our patients had eosinophilia myalgia syndrome, which was related to the ingestion of tryptophan. Other causes of hypereosinophilia seem highly improbable. Thus eosinophilia myalgia syndrome is not a purely American disease.

1 McLearn D. HHS News 1989 Nov 11:89-147.

2 Flannery MT, Wallach PM, Espinoza LR, Dohrenwend MP, Moscinski LC. A case of the eosinophilia-myalgia syndrome associated with the use of an case of the eosinophilia-myalgia syndrome associated

3 Travis WD, Kalafer ME, Robin HS, Luibel FJ. Hypersensitivity vasculitis with eosinophilia in a patient taking an L-tryptophan preparation. with eosinophilia in a patient

4 Kilbourne EM, Swygert LA, Philen RM, et al. Interim guidance on the eosinophilia-myalgia syndrome. Ann Intern Med 1990;112:85-7.

5 Acheson D. L-Tryptophan and eosinophilia-myalgia syndrome in the USA. London: Department of Health, 1989. (PL/CMO(89)11.)

(Accepted 24 April 1990) 